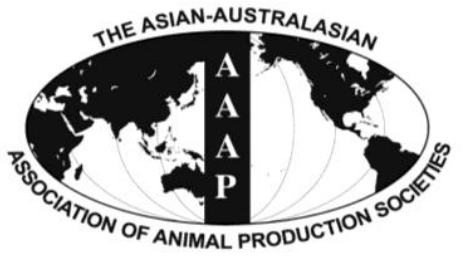

Asian-Aust. J. Anim. Sci.

Vol. 26, No. 2 : 253-259 February 2013

http://dx.doi.org/10.5713/ajas.2012.12479

www.ajas.info

pISSN 101 1-2367 elSSN 1976-5517

\title{
Effects of Enzyme Complex Supplementation to a Paddy-based Diet on Performance and Nutrient Digestibility of Meat-type Ducks
}

\author{
P. Kang, Y. Q. Hou, Derek Toms ${ }^{1}$, N. D. Yan, B. Y. Ding* and Joshua Gong ${ }^{2}$ \\ Hubei Key Laboratory of Animal Nutrition and Feed Science, Wuhan Polytechnic University, Wuhan, Hubei, China
}

\begin{abstract}
Paddy rice is rarely used as a feed because of its high fiber content. In this study, two experiments were conducted to study the effects of supplementing an enzyme complex consisting of xylanase, beta-glucanase and cellulase, to paddy-based diets on the performance and nutrient digestibility in meat-type ducks. In the both experiments, meat-type ducks (Cherry Valley) were randomly assigned to four treatments. Treatment 1 was a basal diet of corn-soybean; treatment 2 was a basal diet of corn-paddy-soybean; treatment 3 , had enzyme complex added to the corn-paddy-soybean basal diet at levels of $0.5 \mathrm{~g} / \mathrm{kg} \mathrm{diet}$; and treatment 4 , had enzyme complex added to the corn-paddy-soybean diet at levels of $1.0 \mathrm{~g} / \mathrm{kg}$ diet. The results showed that the enzyme complex increased the ADG, and decreased the ADFI and F/G significantly $(\mathrm{p}<0.05)$ in the ducks, and the ADFI for the ducks fed the corn-paddy-soybean diet showed no difference compared to the ducks fed corn-soybean diets at all stages of the experiment $(\mathrm{p}<0.05)$. When corn was partially replaced by paddy, the digestibility of CP and NDF was decreased and increased, respectively $(\mathrm{p}<0.05)$, and the level of enzyme complex had a significant effect on both CP and NDF digestibility $(\mathrm{p}<0.05)$. As for the AME, addition of enzyme complex increased it significantly $(\mathrm{p}<0.05)$, but both diet types and levels of enzyme complex had no effect ( $p>0.05)$. The outcome of this research indicates that the application of enzyme complex made up of xylanase, beta-glucanase, and cellulase, in the corn-paddy-soybean diet, can improve performance and nutrition digestibility in meat-type ducks. (Key Words: Xylanase, beta-Glucanase, Cellulase, Paddy, Ducks)
\end{abstract}

\section{INTRODUCTION}

Roughage (>18\% crude fiber) is limited in the nonruminant animal diet because of high fiber levels. Janssen and Carré (1985) indicated that the fibrous components of feed negatively affected chick growth and recommended a reduction in the fiber content of diets for young chicks. But other researchers indicated that an adequate type and amount of fiber might improve adaptation of the gastrointestinal tract (GIT) of poultry to current productive systems (Mateos et al., 2002; Montagne et al., 2003; González-Alvarado et al., 2008) and reduce digestive disturbances (Mateos et al., 2002; Montagne et al., 2003), and chicks might have a requirement for a minimal amount of fiber (Hetland et al., 2005; González-Alvarado, 2007).

Paddy, including hull, bran, bran residue, cereal germ

\footnotetext{
* Corresponding Author: B. Y. Ding. Tel: +86-27-839-56175, Fax: +86-27-839-56175, E-mail: dbying7471@126.com

${ }^{1}$ Department of Animal and Poultry Science, University of Guelph, Guelph, Ontario, Canada.

${ }^{2}$ Guelph Food Research Centre, Agriculture and Agri-Food Canada, Guelph, Ontario, Canada.

Submitted Sept. 6, 2012; Accepted Oct. 22, 2012; Revised Nov. 1, 2012
}

and endosperm, is individual rice kernels that are in their natural, unprocessed state. In 2010, the yield of paddy rice had reached 9.25 million tons in China. Rice hull represents approximately $20 \%$ of unmilled rice (White, 1966), and is usually used as a litter material for poultry, root substrates for greenhouses, or waste material ploughed into the soil or burnt. Noland and Gainer (1953) reported that while unprocessed rice hulls could cause digestive problems, grinding them could eliminate these in gestating-lactating ewes. Bran, because of hydrolytic and oxidative rancidity development, phytate content, enzyme inhibition, and high fiber content, is also limited in its use. In feedstuff, the maximum amount of bran is not more than $20 \%$ (Gallinger et al., 2004). Most previous studies have focused on bran (White, 1966; White and Hembry, 1982; Gallinger et al., 2004), with little attention to the inclusion of paddy ricein feed, and have shown that the use of enzymes, such as phytase and cellulose, could increase the value of feeding bran. Other enzymes, such as $\beta$-glucanase and xylanase, have been mainly used on wheat-based diets.

The low nutrient digestibility in paddy rice is caused by non-starch polysaccharides (NSP, especially with high fiber content), indicating that $\beta$-glucanase, cellulose and xylanase 
supplementation may increase nutrient availability and improve the performance of poultry; partially replacing conventional energy-providing feed such as corn in poultry diets with low-cost paddy rice can be economically attractive. Enzyme supplementation might improve broiler performance by at least two mechanisms: increasing feed intake and improving nutrient digestibility (Lázaro et al., 2003). Consequently, the objective of the present study was to determine the performance responses and nutrient digestibility in meat-type ducks to an enzyme complex consisting of $\beta$-glucanase, cellulose and xylanase, in diets where the corn was partially replaced by paddy.

\section{MATERIALS AND METHODS}

\section{General}

The enzyme complex formulation was based on recommendations by the manufacturer (Wuhan Sunhy Biology Co., Ltd., Hubei, China) and previous experiments in our lab: the levels of xylanase (endo-1,4- $\beta$-xylanase; EC 3.2.1.8), beta-glucanase (endo-1,3 (4) -beta-glucanase EC 3.2.1.6 -) and cellulase (EC 3.2.1.4) were 4,400 IU/kg, $4,300 \mathrm{IU} / \mathrm{kg}$, and $2,400 \mathrm{IU} / \mathrm{kg}$, respectively. One IU of xylanase activity is defined as the amount of the enzyme that generated $1 \mu \mathrm{mol}$ of the xylose from xylan per minute at $\mathrm{pH} 5.5$ and $50^{\circ} \mathrm{C}$. One IU of beta-glucanase activity is defined as the amount of the enzyme that generated $1 \mu \mathrm{mol}$ of the reducing sugar glucose from beta-glucan per minute at $\mathrm{pH} 4.8$ and $50^{\circ} \mathrm{C}$. One IU of cellulase activity is defined as the amount of the enzyme that generated $1 \mu \mathrm{mol}$ of the reducing sugar glucose from sodium carboxymethyl cellulose per minute at $\mathrm{pH} 4.8$ and $37^{\circ} \mathrm{C}$.

\section{Experiment 1}

A total of 324 0-d-old meat-type ducks (Cherry Valley), were raised in net enclosures with free access to feed and water. The ducks were randomly assigned to four treatments, each treatment having three pens, and each pen having 27 ducks. Treatment 1 was a basal diet of corn-soybean; treatment 2 was a basal diet of corn-paddy-soybean; treatment 3 , had enzyme complex added to the corn-paddysoybean basal diet at levels of $0.5 \mathrm{~g} / \mathrm{kg}$ diet; and treatment 4 , had enzyme complex added to the corn-paddy-soybean diet at levels of $1.0 \mathrm{~g} / \mathrm{kg}$ diet. All the basal diets were formulated to meet or exceed NRC (1994) recommendations for all nutrients (Table 1), and the gross energy (GE) and crude protein (CP) among the treatments were almost equal. Paddy rice nutrient content were shown in Table 2. Feed consumption was measured and ducks were weighed on $\mathrm{d} 0$, $7,14,21,28$, and 35 , to calculate average daily gain (ADG), average daily feed intake (ADFI), and the ratio of feed and gain $(\mathrm{F} / \mathrm{G})$.

\section{Experiment 2}

A total of 60 ducks at $36 \mathrm{~d}$ old, were randomly divided into four treatments (the same as in Experiment 1) with 15

Table 1. Composition and nutrient content of diets

\begin{tabular}{|c|c|c|c|c|}
\hline Ingredients (\%) & Treatment 1 & Treatment 2 & Treatment 3 & Treatment 4 \\
\hline Corn & 52.35 & 32.35 & 32.30 & 32.25 \\
\hline Paddy & 0 & 20.00 & 20.00 & 20.00 \\
\hline Soybean meal & 32.25 & 32.25 & 32.25 & 32.25 \\
\hline Rice bran & 8.00 & 8.00 & 8.00 & 8.00 \\
\hline Soybean oil & 1.69 & 1.69 & 1.69 & 1.69 \\
\hline Fish meal & 1.50 & 1.50 & 1.50 & 1.50 \\
\hline $\mathrm{CaHPO}_{4}$ & 1.41 & 1.41 & 1.41 & 1.41 \\
\hline Limestone & 1.11 & 1.11 & 1.11 & 1.11 \\
\hline Salt & 0.34 & 0.34 & 0.34 & 0.34 \\
\hline Methionine (Met) & 0.25 & 0.25 & 0.25 & 0.25 \\
\hline Antimold agent & 0.10 & 0.10 & 0.10 & 0.10 \\
\hline Vitamin-minerals premix ${ }^{a}$ & 1.00 & 1.00 & 1.00 & 1.00 \\
\hline Enzyme complex ${ }^{\mathrm{b}}$ & 0 & 0 & 0.05 & 0.10 \\
\hline \multicolumn{5}{|l|}{ Nutrient levels ${ }^{c}$} \\
\hline Gross energy GE (kcal/kg) & 4,062 & 4,009 & 4,009 & 4,009 \\
\hline Crude protein $\mathrm{CP}(\%)$ & 18.86 & 18.37 & 18.37 & 17.37 \\
\hline Crude fiber $\mathrm{CF}(\%)$ & 2.98 & 4.47 & 4.47 & 4.47 \\
\hline Calcium $\mathrm{Ca}(\%)$ & 0.90 & 0.90 & 0.90 & 0.90 \\
\hline Available phosphorus AP (\%) & 0.40 & 0.40 & 0.40 & 0.40 \\
\hline
\end{tabular}

${ }^{a}$ Premix provided for one kilogram of complete feed: 1,200,000 IU Vitamin A; 250,000 IU Vitamin $\mathrm{D}_{3} ; 2,000 \mathrm{IU}$ Vitamin E, $100 \mathrm{mg}$ Vitamin $\mathrm{B}_{1}, 800 \mathrm{mg}$ Vitamin $\mathrm{B}_{2} ; 200 \mathrm{mg}$ Vitamin $\mathrm{B}_{6} ; 1 \mathrm{mg}$ Vitamin $\mathrm{B}_{12} ; 200 \mathrm{mg}$ Vitamin $\mathrm{K}_{3} ; 15 \mathrm{mg}$ Biotin; $200 \mathrm{mg}$ Folic acid; 7,500 mg Niacin; $1,500 \mathrm{mg}$ pantothenate; $8 \mathrm{~g}$ $\mathrm{Mn}$ (as manganese sulfate); $12 \mathrm{~g} \mathrm{Zn}$ (as zinc sulfate); $10 \mathrm{~g} \mathrm{Fe}$ (as ferrous of sulfate); $0.5 \mathrm{~g} \mathrm{Cu}$ (as copper sulfate); $0.1 \mathrm{~g} \mathrm{I} ; 30 \mathrm{mg}$ Se (as sodium selenite).

${ }^{\mathrm{b}}$ Enzyme complex was composed of 4,400 IU/kg xylanase, 4,300 IU/kg beta-glucanase, and 2,400 IU/kg cellulase.

${ }^{\mathrm{c}}$ The value of gross energy $(\mathrm{GE})$, crude protein $(\mathrm{CP})$, and crude fiber $(\mathrm{CF})$ were actual measured values. 
Table 2. Nutrient content of paddy rice

\begin{tabular}{lc}
\hline Nutrient content $^{\mathrm{a}}$ & \\
\hline Gross energy GE $(\mathrm{kcal} / \mathrm{kg})$ & 2,209 \\
Crude protein CP $(\%)$ & 8.1 \\
Crude fiber CF (\%) & 12.8 \\
Calcium Ca (\%) & 0.03 \\
Total phosphorus TP $(\%)$ & 0.35 \\
\hline
\end{tabular}

${ }^{a}$ The value of nutrient content were all actual measured values.

ducks per treatment, to conduct digestibility studies. The diet intake was measured and excreta were collected over a 3-d period for each duck after an adjustment period of $7 \mathrm{~d}$. The four test diets had $0.3 \%$ chromium oxide added as an inert and indigestible indicator. In order to avoid ammonia volatilization, $4 \mathrm{ml} \mathrm{10 \%} \mathrm{sulfuric} \mathrm{acid} \mathrm{solution} \mathrm{was} \mathrm{added}$ into fresh excreta. The fecal samples were dried in a forcedair drying oven at $60^{\circ} \mathrm{C}$ for $72 \mathrm{~h}$ and ground with a Wiley mill using a 1-mm screen for chemical analysis. A complete proximate analysis was made on the feed sample and on all fecal samples representing total collections. Analyses for dry matter (DM), crude protein (CP), and neutral detergent fiber (NDF) were determined by AOAC (2005) methods, and gross energy (GE) was determined by using bomb calorimetry (Model HWR-15C, Shangli Instruments, Shanghai, China). The AMEn values were calculated by subtracting GE excreted (adjusted to zero $\mathrm{N}$ balance) from GE intake and dividing this value by DM feed intake. The AME was corrected to zero $\mathrm{N}$ balance (AMEn) according to Hill and Anderson (1958). Chromic oxide determination was made on all samples by a modification of the spectrophotometric procedure outlined by Fenton and Fenton (1979).

\section{Statistical analysis}

Statistical analysis was conducted using the GLM procedure in the SAS software program (SAS Inst. Inc., Cary, NC, USA) with a randomized complete block design. The pen was used as the experimental unit for the analysis of growth performance and energy and nutrient digestibility data. p-values of $<0.05$ were considered significant.

\section{RESULTS}

\section{Experiment 1}

As shown in Table 3, on d 35 ducks fed the corn-paddysoybean were on average $2.15 \mathrm{~kg}$ lighter than ducks fed the corn-soybean diet $(\mathrm{p}<0.05)$. When the enzyme complex was added to the corn-paddy-soybean diets at $0.5 \mathrm{~g} / \mathrm{kg}$ and 1.0 $\mathrm{kg} / \mathrm{g}$, the final $\mathrm{BW}$ was $2.28 \mathrm{~kg}$ and $2.32 \mathrm{~kg}$, respectively, and significantly higher than the two unmodified basal diets $(p<0.05)$. The ADG, ADFI, and F/G, however, showed no difference among treatments $(p>0.05)$ from $\mathrm{d} 0$ to 7 . For $\mathrm{d} 7$ to 21 , the enzyme complex increased the ADG $(\mathrm{p}<0.05)$, decreased the ADFI $(\mathrm{p}<0.05)$ and $\mathrm{F} / \mathrm{G}$, with treatment II showing the highest $F / G(p<0.05)$. The enzyme complex added in the corn-paddy-soybean diet increased the ADG and decreased $\mathrm{F} / \mathrm{G}$ from $\mathrm{d} 22$ to 35 , but increasing levels of enzyme complex had no effect $(p>0.05)$. Overall, the enzyme complex increased the ADG, and decreased the ADFI and F/G significantly $(\mathrm{p}<0.05)$ in the ducks, and the ADFI for ducks fed the corn-paddy-soybean diet was no difference from ducks fed the corn-soybean diets at all stage of the experiment $(\mathrm{p}<0.05)$.

\section{Experiment 2}

The digestibility of the diets is shown in Table 4. As shown, the digestibility of CP increased with the level of enzyme complex added $(\mathrm{p}<0.05)$, and ducks had the lowest $\mathrm{CP}$ digestibility for the basal diets of corn-paddy-soybean among all treatments $(\mathrm{p}<0.05)$. As for the AME, the enzyme complex significantly increased it $(\mathrm{p}<0.05)$, but diet type and an increased enzyme complex level had no effect on it $(p>0.05)$. The NDF digestibility was increased with the addition of enzyme complex and showed a further increased digestibility at higher feed levels $(\mathrm{p}<0.05)$.

\section{DISCUSSION}

\section{Performance}

Both corn and rice are energy-containing feed. Mateos et al. $(2006,2007)$ concluded that the use of rice as a substitute for corn improved nutrient digestibility and productive performance in piglets. However, being high in energy and poor in fiber content (Vicente et al., 2008), the addition of rice to the diet may compromise GIT health in young birds (González-Alvarado et al., 2008). Hetland et al. (2005) observed that birds consumed increased amounts of litter when their diet did not provide a minimal amount of fiber. Thus, chicks might require a minimal amount of fiber in the diet to stimulate the development of the upper gastrointestinal tract (González-Alvarado et al., 2008), suggesting that the use of rice as a substitute for corn is more suitable for piglets than for chicks. GonzálezAlvarado et al. (2008) added two sources of hull, oat and soy, into rice-based diets and found the relative weight of the proventriculus and gizzard increased. Paddy, because of the high fiber content, is rarely used in feed. Our main purpose in this study was to determine the effect of an enzyme complex of xylanase, glucanase, and cellulase, on the performance and nutrition digestibility in ducks, when corn in the diet was partially replaced by paddy.

Chicks may require a minimal amount of fiber in their diet to stimulate gastric emptying, and improve absorption and utilization of nutrients (Wilson, 1987), resulting in an improved growth performance. Too high of a level of fiber is also not desirable; in our study, when corn was partially 
Table 3. The effect of the enzyme complex on the growth performance in ducks

\begin{tabular}{|c|c|c|c|c|}
\hline Index & Treatment 1 & Treatment 2 & Treatment 3 & Treatment 4 \\
\hline Initial BW (g) & $59.49 \pm 0.043$ & $59.47 \pm 0.077$ & $59.46 \pm 0.057$ & $59.43 \pm 0.113$ \\
\hline Final BW (g) & $2,183.97 \pm 15.21^{\mathrm{c}}$ & $2,148.89 \pm 11.10^{\mathrm{d}}$ & $2,287.13 \pm 10.21^{\mathrm{b}}$ & $2,322.34 \pm 22.79^{\mathrm{a}}$ \\
\hline \multicolumn{5}{|l|}{1 to $7 \mathrm{~d}$} \\
\hline ADG (g/d) & $16.20 \pm 0.010$ & $16.19 \pm 0.011$ & $16.21 \pm 0.040$ & $16.24 \pm 0.016$ \\
\hline ADFI (g/d) & $20.71 \pm 0.026$ & $20.68 \pm 0.084$ & $20.70 \pm 0.037$ & $20.66 \pm 0.018$ \\
\hline F/G & $1.28 \pm 0.0024$ & $1.28 \pm 0.0047$ & $1.28 \pm 0.0033$ & $1.27 \pm 0.0021$ \\
\hline \multicolumn{5}{|l|}{8 to $14 \mathrm{~d}$} \\
\hline ADG $(\mathrm{g} / \mathrm{d})$ & $57.55 \pm 0.061^{\mathrm{b}}$ & $57.37 \pm 0.250^{\mathrm{b}}$ & $57.95 \pm 0.180^{\mathrm{a}}$ & $58.21 \pm 0.098^{\mathrm{a}}$ \\
\hline ADFI (g/d) & $82.49 \pm 0.021^{\mathrm{b}}$ & $82.73 \pm 0.150^{\mathrm{a}}$ & $82.31 \pm 0.012^{c}$ & $82.20 \pm 0.039^{c}$ \\
\hline $\mathrm{F} / \mathrm{G}$ & $1.43 \pm 0.0019^{\mathrm{b}}$ & $1.44 \pm 0.0038^{\mathrm{a}}$ & $1.42 \pm 0.0042^{\mathrm{c}}$ & $1.41 \pm 0.0028^{\mathrm{d}}$ \\
\hline \multicolumn{5}{|l|}{15 to $21 \mathrm{~d}$} \\
\hline ADG (g/d) & $66.99 \pm 0.270^{\mathrm{b}}$ & $64.91 \pm 0.310^{c}$ & $68.15 \pm 0.790^{\mathrm{a}}$ & $68.07 \pm 0.510^{\mathrm{a}}$ \\
\hline ADFI (g/d) & $133.40 \pm 0.850^{\mathrm{a}}$ & $131.58 \pm 0.470^{\mathrm{b}}$ & $132.40 \pm 0.610^{\mathrm{ab}}$ & $127.63 \pm 0.260^{c}$ \\
\hline $\mathrm{F} / \mathrm{G}$ & $1.99 \pm 0.018^{\mathrm{b}}$ & $2.03 \pm 0.00061^{\mathrm{a}}$ & $1.94 \pm 0.015^{\mathrm{c}}$ & $1.8 \pm 0.080^{\mathrm{d}}$ \\
\hline \multicolumn{5}{|l|}{22 to $28 \mathrm{~d}$} \\
\hline ADG (g/d) & $90.87 \pm 0.990^{\mathrm{ab}}$ & $87.62 \pm 2.120^{\mathrm{b}}$ & $95.32 \pm 2.940^{\mathrm{a}}$ & $93.81 \pm 4.760^{\mathrm{a}}$ \\
\hline ADFI (g/d) & $196.18 \pm 1.800$ & $196.01 \pm 3.810$ & $198.19 \pm 0.670$ & $187.44 \pm 13.330$ \\
\hline $\mathrm{F} / \mathrm{G}$ & $2.16 \pm 0.023^{\mathrm{ab}}$ & $2.24 \pm 0.092^{\mathrm{a}}$ & $2.08 \pm 0.067^{\mathrm{bc}}$ & $2.00 \pm 0.058^{c}$ \\
\hline \multicolumn{5}{|l|}{29 to $35 \mathrm{~d}$} \\
\hline $\mathrm{ADG}(\mathrm{g} / \mathrm{d})$ & $90.71 \pm 2.120^{\mathrm{bc}}$ & $89.52 \pm 1.650^{\mathrm{c}}$ & $93.81 \pm 0.860^{\mathrm{ab}}$ & $96.31 \pm 1.730^{\mathrm{a}}$ \\
\hline ADFI (g/d) & $232.06 \pm 1.810^{\mathrm{ab}}$ & $234.42 \pm 0.660^{\mathrm{a}}$ & $231.82 \pm 1.770^{\mathrm{ab}}$ & $231.17 \pm 0.610^{\mathrm{b}}$ \\
\hline $\mathrm{F} / \mathrm{G}$ & $2.56 \pm 0.054^{\mathrm{a}}$ & $2.62 \pm 0.051^{\mathrm{a}}$ & $2.47 \pm 0.019^{\mathrm{b}}$ & $2.40 \pm 0.049^{\mathrm{b}}$ \\
\hline \multicolumn{5}{|l|}{1 to $35 \mathrm{~d}$} \\
\hline ADG (g/d) & $60.70 \pm 0.430^{c}$ & $59.70 \pm 0.320^{\mathrm{d}}$ & $63.65 \pm 0.290^{\mathrm{b}}$ & $64.65 \pm 0.650^{\mathrm{a}}$ \\
\hline ADFI (g/d) & $133.01 \pm 0.080^{\mathrm{a}}$ & $133.04 \pm 0.490^{\mathrm{a}}$ & $133.08 \pm 0.510^{\mathrm{a}}$ & $129.82 \pm 0.540^{\mathrm{b}}$ \\
\hline $\mathrm{F} / \mathrm{G}$ & $2.19 \pm 0.021^{\mathrm{b}}$ & $2.23 \pm 0.084^{\mathrm{a}}$ & $2.09 \pm 0.052^{\mathrm{c}}$ & $2.01 \pm 0.043^{\mathrm{d}}$ \\
\hline
\end{tabular}

Values are presented as means \pm SD. Means in a row with different letters differ significantly $(\mathrm{p}<0.05)$.

replaced by paddy, the ducks showed a decreased BW by the end of the experiment. This result confirmed the results of previous studies in chicks (Kratzer and Payne, 1977; Hussein and Kratzer, 1982), which suggest that this might be due, at least in part, to the fiber content in corn-paddysoybean diet, which was beyond the minimum requirement and might compromise GIT health in ducks. Consistent with our metabolism experiment results, high fiber content had side effects on the nutrient digestibility in the ducks.

Rice hull, a high NSP source, has detrimental effects on performance in layers (van Krimpen et al., 2008). Thus, supplementation of NSP-degrading enzymes in high-NSP diets is one approach to reduce detrimental effects of NSP and improve the nutritional value for young birds. In the current study, when the enzyme complex was added to the corn-paddy-soybean basal diet, the ADG and G/F were improved to a level even greater than the corn-soybean diet. Previous studies have shown that the addition of xylanase and $\beta$-glucanase to rye-based diets improved performance in birds (Frigard et al., 1994; Langhout et al., 1997), and the levels of these two enzymes was higher than in our study. Ravindran et al. (1999) indicated that exogenous xylanases and glucanases could improve the performance of broiler chickens fed diets based on wheat and barley. These additions were related to greater digestion and absorption of nutrients, and degradation of cell wall NSP by both xylanases and glucanases has been proposed as the main contributing factor (Bedford and Schulze, 1998). That the ADG, ADFI, and F/G showed no difference among treatments between d 0 to 7 may have resulted from a lower feed intake. In the whole experimental timeframe, with increased levels of enzyme complex, the ADFI decreased

Table 4. The effect of the enzyme complex on apparent digestibility of nutrients in ducks

\begin{tabular}{lllll}
\hline Index & Treatment 1 & Treatment 2 & Treatment 3 & Treatment 4 \\
\hline Crude protein (CP, \%) & $72.31 \pm 0.44^{\mathrm{c}}$ & $69.27 \pm 0.24^{\mathrm{d}}$ & $76.18 \pm 0.14^{\mathrm{b}}$ & $77.04 \pm 0.28^{\mathrm{a}}$ \\
Apparent metabolizable energy (AME, \%) & $70.14 \pm 0.11^{\mathrm{b}}$ & $69.87 \pm 0.59^{\mathrm{b}}$ & $72.51 \pm 0.21^{\mathrm{a}}$ & $73.32 \pm 0.17^{\mathrm{a}}$ \\
Neutral detergent fiber (NDF, \%) & $30.64 \pm 0.057^{\mathrm{d}}$ & $31.28 \pm 0.23^{\mathrm{c}}$ & $36.42 \pm 0.14^{\mathrm{b}}$ & $37.16 \pm 0.11^{\mathrm{a}}$ \\
\hline
\end{tabular}

Values are presented as means \pm SD. Means in a row with different letters differ significantly $(\mathrm{p}<0.05)$. 
significantly, which may be because of: i) extra released nutrients; or ii) a nutrient imbalance, both of these combined leading to improved nutrient digestibility with a lowered ADFI (Nortey et al., 2007). Compared to treatments without the addition of enzyme complex, the ADG of birds fed diets with low and high levels of enzyme complex was increased from $5 \%$ to $6 \%$, and from $6 \%$ to $8 \%$, respectively, which could have been due to increased digestibility of nutrients. In our study, the ADG was not linearly correlated with feed intake, suggesting that the enzyme complex was effective in stimulating the utilization of nutrients.

García et al. (2008) concluded that barley with an enzyme complex of $\beta$-glucanase and xylanase, could wholly replace corn in diets fed to broilers from d 1 to 21 of age; enzymes improved digestive traits, retention of nutrients, and broiler performance from d 1 to 42 . In the current study, under the action of the enzyme complex used, whether or not paddy ricecould completely replace corn is in need of further research.

\section{Metabolism digestibility}

Nutrients, such as starches, proteins, and lipids, are enclosed by the cell walls, and supplying enzymes to enhance the breakdown of the cell wall components can increase exposure of these nutrients to the digestive system. Bedford and Schulze (1998) concluded that degradation of cell wall NSP by both xylanases and glucanases is the main contributing factor to the greater digestion and absorption of nutrients and great performance. Nahm and Carlson (1985) reported that cellulase supplementation significantly improved the digestibility of cell wall components.

NSP-degrading enzymes can improve energy utilization of high-NSP diets in young pigs. Previous studies have shown that xylanase could improve apparent AA, energy, and DM digestibility in wheat-based diets for grower pigs (Barrera et al., 2004; Nortey et al., 2007). Ravindran et al. (1999) concluded that xylanase was beneficial in terms of protein and energy utilization, and growth performance for broilers, but could not eliminate other enzyme functions as the xylanase was a blend that also contained $\beta$-glucanase, cellulase, hemi-cellulase, and protease. In the current study, the digestibility of CP was higher in the corn diet than in the corn-paddy rice diet, which likely resulted from the higher fiber content in the latter, which would inhibit the CP digestion and absorption as an increase in dietary fiber content might increase ileal losses of both endogenous and exogenous protein (Schulze et al., 1994).

The addition of enzyme complex improved the $\mathrm{CP}$, AME, and NDF digestibility, which could be associated with the development of GIT and lower digesta viscosity. González-Alvarado et al. (2007) showed that the effects of hulls on the relative weight of the gizzard and on the total tract apparent retention of nutrients, were more pronounced in rice diets than for corn diets. Diebold et al. (2004) concluded that xylanase could stimulate the development of GIF resulting from volatile fatty acids (VFA). Lázaro et al. (2003) concluded that $500 \mathrm{ppm}$ of an enzyme complex containing $\beta$-glucanase and xylanase added to rye diets decreased intestinal viscosity, accelerated digestive transit, and improved productive performance of broilers. Malathi and Devegowda (2001) also shown that a complex of xylanase, cellulase, and $\beta$-glucanase significantly reduced the relative viscosity of the digesta in vitro.

Ravindran et al. (1999) found that the complex of xylanase and $\beta$-glucanase had no effect on the AME content of barley, perhaps because the levels of substrates in barley were too low to show an energy response. On the other hand, in the current study, the enzyme complex increased the AME digestibility possibly due to: i) enough substrate for the enzyme; or ii) a complimentary effect between the three enzymes used. However, others studies have shown that a $\beta$-glucanase and xylanase cocktail in Canola mealbased diets have no pronounced effect on the growth performance or nutrient digestibility (Mushtaq et al., 2007).

In the current study, as birds do not possess enzymes to hydrolyze NDF, the increased digestibility of NDF when the corn was partially replaced by paddy, was most likely a result of bacterial fermentation (Schulze et al., 1994). At the same level of NDF, the digestibility of NDF was increased with the inclusion of enzyme complex, showing a more substantial effect from enzyme activity than from bacterial fermentation on NDF digestability.

\section{CONCLUSION}

Because supplementation with the enzyme complex, consisting of xylanase, beta-glucanase, and cellulase, improved performance, and increased CP, AME, and NDF digestibility values over an non-supplemented basal diet, it can be concluded that the effects of adding the enzyme complex was positive when corn was partially replaced by paddy ricein duck feed. The summed effects of xylanase, beta-glucanase, and cellulase may reflect more or less consistent results obtained by a supplementation of enzyme combinations. Whether a linear relationship exists between performance and enzyme levels, and whether the corn component of the diet could be completely replaced by paddy rice with appropriate levels of enzyme complex are in need further study, but represent an exciting area of research into using low-cost paddy ricein duck feed.

\section{ACKNOWLEDGEMENTS}

This research was jointly supported by National Agriculture Science and Technology fund projects of China 
(Grant No. 2011GB2D100014), Hubei Provincial Research and Development Program (Grant No. 2010BB023), and Natural Science Foundation of Hubei Province (Grant No. 2011CDA051).

\section{REFERENCES}

AOAC. 2005. Official methods of analysis. 17th ed. Assoc. Off. Anal. Chem., Arlington, VA, USA.

Barrera, M., M. Cervantes, W. C. Sauer, A. B. Araiza, N. Torrentera and M. Cervantes. 2004. Ileal amino acid digestibility and performance of growing pigs fed wheat-based diets supplemented with xylanase. J. Anim. Sci. 82:1997-2003.

Bedford, M. R. and H. Schulze. 1998. Exogenous enzymes in pigs and poultry. Nutr. Res. Rev. 11:91-114.

Diebold, G., R. Mosenthin, H. P. Piepho and W. C. Sauer. 2004. Effect of supplementation of xylanase and phospholipase to a wheat-based diet for weanling pigs on nutrient digestibility and concentrations of microbial metabolites in ileal digesta and feces. J. Anim. Sci. 82:2647-2656.

Fenton, T. W. and M. Fenton. 1979. An improved method for chromic oxide determination in feed and feces. Can J. Anim. Sci. 59:631-634.

Frigard, T., D. Pettersson and P. Åman. 1994. Fiber-degrading enzyme increases body weight and total serum cholesterol in broiler chickens fed a rye-based diet. J. Nutr. 124:2422-2430.

Gallinger, C. I., D. M. Suárez and A. Irazusta. 2004. Effects of rice bran inclusion on performance and bone mineralization in broiler chicks. J. Appl. Poult. Res. 13:183-190.

García, M., R. Lázaro, M. A. Latorre, M. I. Gracia and G. G. Mateos. 2008. Influence of enzyme supplementation and heat processing of barley on digestive traits and productive performance of broilers. Poult. Sci. 87:940-948.

González-Alvarado, J. M., E. Jiménez-Moreno, D. G. Valencia, R. Lázaro and G. G. Mateos. 2008. Effects of fiber source and heat processing of the cereal on the development and $\mathrm{pH}$ of the gastrointestinal tract of broilers fed diets based on corn or rice. Poult. Sci. 87:1779-1795.

González-Alvarado, J. M., E. Jiménez-Moreno, R. Lázaro and G. G. Mateos. 2007. Effect of type of cereal, heat processing of the cereal, and inclusion of fiber in the diet on productive performance and digestive traits of broilers. Poult. Sci. 86: 1705-1715.

Hetland, H., B. Svihus and M. Choct. 2005. Role of insoluble fiber on gizzard activity in layers. J. Appl. Poult. Res. 14:38-46.

Hill, F. W. and D. L. Anderson. 1958. Comparison of metabolisable energy and productive energy determinations with growing chicks. J. Nutr. 64:587-603.

Hussein, A. S. and F. H. Kratzer. 1982 Effect of rancidity on the feeding value of rice bran for chickens. Poult. Sci. 61:24502455.

Janssen, W. M. M. A. and B. Carré. 1985. Influence of fibre on digestibility of poultry feeds. Pages 71-86 In: Recent Advances in Animal Nutrition (Ed. W. Haresign and D. J. A. Cole). Butterworths, London, UK.

Kratzer, F. H. and C. G. Payne. 1977. Effect of autoclaving, hotwater treating, parboiling and addition of ethoxyquin on the value of rice bran as a dietary ingredient for chickens. Br.
Poult. Sci. 18:475-482.

Langhout, D. J., J. B. Schutte, C. Geerse, A. K. Kies, J. De Jong and M. W. A.Verstegen. 1997. Effects on chick performance and nutrient digestibility on an endo-xylanase added to a wheat-andrye-based diet in relation to fat source. Br. Poult. Sci. 38:557-563.

Lázaro, R., M. García, P. Medel and G. G. Mateos. 2003. Inluence of enzymes on performance and digestive parameters of broilers fed rye-based diets. Poult. Sci. 82:132-140.

Malathi, V. and G. Devegowda. 2001. In vitro evaluation of nonstarch polysaccharide digestibility of feed ingredients by enzymes. Poult. Sci. 80:302-305.

Mateos, G. G., E. López, M. A. Latorre, B. Vicente and R. Lázaro. 2007. The effect of inclusion of oat hulls in piglet diets based on raw or cooked rice and maize. Anim. Feed Sci. Technol. 135:100-112.

Mateos, G. G., F. Martín, M. A. Latorre, B. Vicente and R. Lázaro. 2006. Inclusion of oat hulls in diets for young pigs based on cooked maize or cooked rice. Anim. Sci. 82:57-63.

Mateos, G. G., R. Lázaro and M. Gracia. 2002. The feasibility of using nutritional modifications to replace drugs in poultry feeds. J. Appl. Poult. Res. 11:437-452.

Montagne, L., J. R. Pluske and D. J. Hampson. 2003. A review of interactions between dietary fibre and the intestinal mucosa, and their consequences on digestive health in young nonruminant animals. Anim. Feed Sci Technol. 108:95-117.

Mushtaq, T., M. Sarwar, G. Ahmad, M. A. Mirza, H. Nawaz, M. M. Haroon Mushtaq and U. Noreen. 2007. Influence of canola meal-based diets supplemented with exogenous enzyme and digestible lysine on performance, digestibility, carcass, and immunity responses of broiler chickens. Poult. Sci. 86:21442151.

Nahm Kee, H. and C. W. Carlson. 1985. Effects of cellulase from Trichoderma viride on nutrient utilization by broilers. Poult. Sci. 64:1536-1540.

Noland, P. A. and J. H. Gainer. 1953. The use of rice hulls as a roughage for wintering steers and for gestating lactating ewes. Arkansas Agric. Exp. Stn. Bull. 538: Fayetteville, AR.

Nortey, T. N., J. F. Patience, P. H. Simmins, N. L. Trottier and R. T. Zijlstra. 2007. Effects of individual or combined xylanase and phytase supplementation on energy, amino acid, and phosphorus digestibility and growth performance of grower pigs fed wheat-based diets containing wheat millrun. J. Anim. Sci. 85:1432-1443.

NRC. 1994. Nutrient requirements of poultry. 9th rev. ed. Natl. Acad. Press, Washington, DC, USA.

Ravindran, V., P. H. Selle and W. L. Bryden. 1999. Effects of phytase supplementation, individually and in combination, with glycanase, on the nutritive value of wheat and barley. Poult. Sci. 78:1588-1595.

Schulze, H., P. Van Leeuwenf, M. W. A. Verstegen, J. Huismant, W. B. Souffkantt and F. Ahrenss. 1994. Effect of level of dietary neutral detergent fiber on ileal apparent digestibility and ileal nitrogen losses in pigs. J. Anim. Sci. 72:2362-2368.

Van Krimpen, M. M., R. P. Kwakkel, C. M. C. Van Der PeetSchwering, L. A. Den Hartog and M. W. A. Verstegen. 2008. Low dietary energy concentration, high nonstarch polysaccharide concentration, and coarse particle sizes of nonstarch polysaccharides affect the behavior of feather- 
pecking-prone laying hens. Poult. Sci. 87:485-496.

Vicente, B., D. G. Valencia, M. P. Serrano, R. Lázaro and G. G. Mateos. 2008. The effects of rice feeding in substitution of corn and the degree of starch gelatinisation of rice on digestibility of dietary components and productive performance of young pigs. J. Anim. Sci. 86:119-126.
White, T. W. 1966. Utilization of ammoniated rice hulls by beef cattle. J. Anim. Sci. 25:25-28.

White, T. W. and F. G. Hembry. 1982. Effect of roughage source and level of digestibility and rates of grain passage by steers. J. Anim. Sci. 55(Suppl. 1):3.

Wilson, G. Pond. 1987. Thoughts on fiber utilization in swine. J. Anim. Sci. 65:497-499. 